\title{
CALVYN SE INSTITUSIE AS HANDBOEK VIR JOHN KNOX*
}

Hoewel John Knox, die Skotse Hervormer oor die algemeen beskou word as 'n calvinis, is daar tot op die huidige datum nog baie onsekerheid en selfs verwarring oor die omvang en die nadere bepaling hiervan. Veral oor die eerste jare van sy optrede, vanaf 1547 tot 1554 toe hy vir die eerste keer Calvyn in Genéve ontmoet het. is daar groot onduidelikheid. Die gevolg hiervan is dat daar nou selfs in die jongste tyd 'n standpunt voorgedra word dat Knox vóór 1554 eerder onder invloed was van I.uther as Calvyn. Die bewyse en doku. mentasie hiervoor is egter so karig. dat ons gedwing word om die geskrifte van Knox en Calvyn self te gaan lees. En so het meteens Knox se teologiese geskrifte voor 1554 en ook die verskillende uit. gawes van Calvyn se Institusie voor 1554 in die gesigsveld gekom. In hierdie vergelykende ondersoek is daar spoedig soveel verrassende materiaal ontdek wat Knox nie alleen in 'n nuwe lig stel as "calvinis" nie, maar wat ook hierdie gedagtegang van ,.eerder l.uther as Calvyn" ('n gedagtegang wat reeds besig was om algemeen pos te vat). finaal die nek inslaan. Trouens die hele benadering van ,.eerder Luther as Calvyn," is nie suiwer nie. want baie bewyse (dink aan die eerste uitgawe van die Institusie in 1536!) kan aangevoer word dat Calvyn weer onder invloed van Luther was.

In Knox se heel eerste geskrif van teologiese aard, nl. "A Vindication of the doctrine that the sacrifice of the Mass is idolutry" (1550), ontdek ons ten eerste 'n slaafse. letterlike navolging van Calvyn se Institusie (1539-uitgawe of daarna voor 1554) en ten tweede. 'n radikale afwyking daarvan. Hierdie afwyking kom veral na vore in die formele manier waarop Knox die Roomse Mis bestry, nl. bloot op die feit dat dit nie die herel van God is nie. Deut. 12:32, een van die sleuteltekste in Knox se teologe. is ook hier die beslissende uitgangspunt.

Ook in Knox se ander geskrifte wat uit hierdie tyd dateer en waaruit sy opvattings on die heilige Nagmaal na vore kom. vind ons ' $n$ bevestiging van die invloed van die Institusie. Hierdie geskrifte is nl. 'n fragment wat oorgebly het van sy ,The Iord's Supper used in Berwick hy John Knox" (waarskynlik 1550) en sy .Epistle to the "ongregation of Berwick" (waarskynlik 1552).

In Knox se "Answers to some Questions concerning Baptism, etc." (waarskynlik 1.556), vind ons wel Knox se godagtes nadat hy

- $\mathrm{Na}$ aanleiding van my studie, ,John Knox and the Institutes of Calvin." "n Volledige dokumentasie vir ons stelling word daarin gevind. (V.F.D.) 
Calvyn reeds ontmoet het, maar ons ontdek in ontwikkelingsgang wat tred hou met die ontwikkeling van Calvyn se gedagtes in die verskilverskillende uitgawes van die Institusie, veral wat betref die kerklike a lende uitgawes van die Institusie, veral wat betref die kerklike aksent t.o.v. die sakramente. Ook Calvyn se beginsel dat Woord en Sakrament nie van mekaar kan geskei word nie, tree hier sterk op die voorgrond.

Een van Knox se geskrifte voor 1554 wat sekerlik die duidelikste letterlike en slaafse navolging van die Institusie vertoon, is sy ,A Declaration of the true Nature and object of Prayer." Feitlik die hele geskrif word in Calvyn se .,De Oratione" van die Institusie (1539. 1554) teruggevind! As daar miskien nog steeds moderne teoloë is wat Knox se afhanklikheid van Calvyn voor 1554 ontken en volhou met 'n ,eerder Luther." opvatting. dan word hierdie geskrif 'n meedoënlose struikelblok.

Die grootste geskrif van teologiese aard wat Knox geskryf het. is sy „On Predestination." Dit was in 1559, en hier tree hy nou vir die eerste keer na vore deur self te verklaar dat hy 'n vurige navolger van Calvyn is, veral wat betref die Institusie. Vir die eerste keer word die Institusie in Knox se geskrifte met verwysings aangehaal en daaruit kan ons bewys dat dit die 1550-uitgawe is wat hy gebruik het. alhoewel dit ook duidelik is, dat hy kennis gedra het van die 1539 . uitgawe.

'n Vergelyking van Knox se „On Predestination” met die Institusie bewys egter dat hy nog meer van die inhoud letterlik oorgeneem het as wat hy self aandui, soos wat o.a. blyk uit sy derinisies van die predestinasie (praedestinatio), die voorsienigheid (providentia) en die voorkennis (praescientia) van God.

Alhoewel Knox openlik in hierdie geskrif probeer om Calvyn se opvattings oor die predestinasie te vertolk, slaag hy slegs ten dele daarin. Formeel is die rede voor-die-hand-liggend, nl. dat ons nie hier 'n tetiese uiteensetting van die leerstuk aantref soos in die Institusie nie, maar 'n apologetiese geskrif, waarin die skema bepaal word deur sy teenstander se argumente. Veral Calvyn se apriori van die Heilige Skrif en die christosentriese karakter in sy predestinasieleer, word by Knox gemis. Knox se melode van benadering laat hom dan weldra in die gevaar van 'n kausale determinisme verval. Dit kom baie duidelik uit in die manier waarop hy die sogenaamde "decretum horrible" of die dubbele predestinasie, hanteer. Waar Calvyn ons aanmaan om ons nie besig te hou met die verborge wil van God nie. maar met die ander oorsaak van die verwerping. nl. die sonde van die mens (soos wat die Skrif dit leer), daar poneer Knox dat die wil van God so absoluut as oorsaak van die verwerping is. dat alle ander oorsake uitgesluit word. In hierdie opsig was Knox 'n voorstander van die gedagtegang wat later die benaming gekry het van die supralapsarisme.

Ondanks baie punte waarin daar 'n saaklike ooreenkoms tussen Calvyn en Knox se leer oor die predestinasie is, sou dit beslis nie 
kan gesê word dat Knox se vertolking 'n suiwer weergawe van Calvyn is nie. Inteendeel, op sekere kardinale punte wyk hy baie ver af.

Behalwe in die bogemelde geskrifte van Knox wat feitlik sy enigste is waarin hy in poging aanwend om teologiese leerstukke in samehangende eenhede te behandel. kan ons tog ook sy opvattings uit sy ander geskrifte verneem. Om nie in ' $n$ oneindige uiteensetting te verval waarin die behandeling naderhand sou oorgaan van belang. rike leerpunte tot minderbelangrike en selfs obskure gedagtes nie. het ons ons beperk tot Knox se opvattings oor God se Woord en die kerk. Dit was trouens die twee belangrikste sake wat in die brandpunt van die Hervorming van die 16de eeu gestaan het.

Oor die formele plek van die Woord lan $G(x)$ in die kerk, was Knox $10(0 \%$ eenstemmig met die ander Hervormers. Saam met Luther en Calvyn het hy die volle gesag van die Woord oor die kerk gehandhaaf. Van hierdie reformatoriese beginsel was hy een van die vurigste voorstanders. Maar wat vir hom die werklike. saaklike betekenis van die Woord was, toon duidelik op groot verskille met Calvyn soos voorgedra in sy Institusie. Die verskilpunte sentreer hoofsaaklik ten eerste deur Knox se formele beklemtoning van Deut. 12:32 as uitgangspunt. ten tweede in sy opvatting oor die Ou en Nuwe Testamente waarin hy feillik die twee identifiseer en ten derde in sy letterlike oorbrenging van Bybelse gebeurtenisse. persone ens., op toestande in die moderne geskiedenis. Die Woord as die ..express commendment" van God. sonder die gesigspunt van die ..historia revelationis," word de beheersende element in sy teologie en verder in die praktiese kerk. like gebruike, soos o.a. in die seremonies en liturgie.

Oor die kerk bestaan daar ewe-eens 'n baie groot ooreenkoms tussen Knox se opvatting en Calvyn se beskouing in sy Institusie en hier is minder ingrypende verskille aan te merk as in die geval van die Woord. Dit kan veral daaraan toegeskryf word dat beide van hulle die Verbond van die Genade as uitgangspunt vir die kerk baie sterk beklemtoon. Hier kom die uitsonderlik verrassende gesigspunt na vore dat beide. Knox en Calvyn die grense van die verbond ruimer stel as slegs die uitverkorenes alleen. So is die grondslag van die verbond vir beide die helofte ian die Evangelie en nie die individuele witverkiesing nie.

Verder word beide, Knox en Calvyn. se beskouing oor die kerk beheers deur die feit dat God Sy kerk alleen vergader deur die prediking van die Evangelie van Jesus Christus. Die Woord is die enigste middel wat deur die Heilige Gees gebruik word om de kerk te bou. Dit is dan die eerste merkteken van die ware kerk en daarby kom vanselfsprekend ook die sigbare Woord, nl. die sakramente. Knox se definisie om die wese van die kerk te verklaar kan dan ook feitlik woordeliks in die Institusie van Calvyn teruggevind word, nl. daar waar die Evangelie van Christus suiwer gepreek word en waar die sakramente soos wat Christus dit ingestel het, bodien word, daar is dic kerk! 
So staan Knox met sy opvattings oor die kerk duidelik in een lyn met Augustinus en Calvyn wat albei verklaar het dat wie God as Vader het, het die kerk as moeder.

Verskille in die beskouing oor die kerk tussen Knox en Calvyn kom saaklik na vore in die beskrywing van die een kerk as die „ecclesia universalis” enersyds en die "singula ecclesia" andersyds. By Knox kan die Skotse kerk ook 'n "universil Kirk" wees waarvan die plaaslike kerke dan onderdele is. By Calvyn sal ons nodeloos in sy Institusie soek waarin die plaaslike kerk as onderdeel van bv. 'n landskerk of 'n volkskerk gehandhaaf word. By hom is die plaaslike gemeente ten volle kerk met volle gesag van die kerk.

In hierdie vergelyking tussen Knox en die Institusie van Calvyn is slegs enkele aunknopingspumte in hulle teologie gegee. Die taak om hierdie vergelyking nog verder uit te bou word gaandeweg vinnig moeiliker en in 'n sekere sin selfs onbegonne. Die rede lế voor die hand: Knox was geen groot teoloog nie en ons moet hom eer dat hy dit self so eerlik en nadruklik verklaar het. Aan die ander kant was Calvyn een van die grotes onder die grootste teoloë van ons bedeling en die stroom literatuur oor sy teologie wat steeds geen einde kry nie, bewys dit.

V. E. d'Assonville. 